Supporting Information

\title{
Simultaneous and Accurate Quantification of Multiple Antibiotics in Aquatic Samples by Surface-Enhanced Raman Scattering Using a Ti3C2Tx/DNA/Ag Membrane Substrate
}

\author{
Zhongning Yü, Lu Huang\#, Zhuomin Zhang*, Gongke Li* \\ School of Chemistry, Sun Yat-sen University, Guangzhou 510275, China.
}

\author{
*Corresponding authors: zzm@mail.sysu.edu.cn (Z.M. Zhang); \\ cesgkl@mail.sysu.edu.cn (G.K. Li) \\ \#These authors contribute equally to this work.
}




\section{Table of Contents}

Subject

S1 Materials and Reagents $\quad$ S3

S2 Instruments $\quad$ S3

S3 The details of COMSOL simulation $\quad$ S3

S4 The computational details of Materials Studio software $\quad$ S3

S5 The pretreatment process of raw samples $\quad$ S4

S6 Optimization of preparation conditions for this substrate $\quad$ S5

$\begin{array}{ll}\text { Figure S1 (Effect of DNA on the substrate preparation) } & \text { S5 }\end{array}$

Figure S2 (Effect of surfactant type on the substrate preparation) S6

Figure S3 (Effect of surfactant amount on the substrate preparation) S6

$\begin{array}{ll}\text { Figure } \mathrm{S} 4 \text { (Effect of } \mathrm{AgNO}_{3} \text { concentration on the substrate preparation) } & \text { S7 }\end{array}$

Figure S5 (Effect of ascorbic acid concentration on the substrate preparation) $\quad$ S8

$\begin{array}{ll}\text { Figure S6 (Effect of membrane loading amount on the substrate preparation) } & \text { S8 }\end{array}$

$\begin{array}{lr}\text { S7 Characterization of this substrate } & \text { S9 }\end{array}$

$\begin{array}{ll}\text { Figure S7 (SEM and EDS mapping analysis) } & \text { S9 }\end{array}$

$\begin{array}{ll}\text { Figure S8 (Zeta potential test) } & \text { S9 }\end{array}$

$\begin{array}{ll}\text { Figure S9 (XRD characterization) } & \mathbf{S 1 0}\end{array}$

$\begin{array}{lr}\text { Figure S10 (XPS characterization) } & \text { S10 }\end{array}$

$\begin{array}{lr}\text { Figure S11 (FT-IR characterization) } & \text { S10 }\end{array}$

Figure S12 (UV-Vis characterization) $\quad$ S11

S8 Reproducibility, stability and SERS activity of this substrate $\quad$ S11

$\begin{array}{lr}\text { Figure S13 (Reproducibility evaluation of this substrate) } & \text { S11 }\end{array}$

Figure S14 (Stability evaluation of this substrate) $\quad$ S12

Figure S15 (SERS activity evaluation of this substrate) $\quad$ S12

S9 Study on the adsorption and enrichment performance of this substrate $\quad$ S13

Figure S16 (UV-Vis spectra of NFT and OFX before and after filtration) $\quad$ S13

S10 Calculation of enhancement factor $\quad$ S13

Figure S17 (The comparison between Raman and SERS spectra of NFT and OFX) S14

$\begin{array}{lr}\text { S11 Study of the CM effect of this substrate } & \text { S14 }\end{array}$

Figure S18 (Interaction models between $\mathrm{Ti}_{3} \mathrm{C}_{2} \mathrm{~T}_{\mathrm{x}}$ and different antibiotics) $\quad$ S14

S12 Simultaneous quantification for trace NFT and OFX in aquatic samples by SERS S15

Figure S19 (SERS spectra of NFT and OFX mixed standard solutions and the corresponding standard curves)

Table S1 (Typical SERS peaks for NFT and OFX)

Table S2 (Comparison of different methods for determination of NFT and OFX)

Table S3 (Simultaneous quantification of trace NFT and OFX in aquatic samples by SERS) $\quad$ S17

$\begin{array}{ll}\text { References } & \text { S18 }\end{array}$ 


\section{S1 Materials and Reagents}

Furazolidone, furaltadone, nitrofurazone, ciprofloxacin, norfloxacin, tobramycin, chloramphenicol, chlorothalonil, benzylpenicillin sodium, and ampicillin were all obtained from J\&K Chemical Co., Ltd. Tween-20 (T-20), sodium dodecyl sulfonate (SDS) and cetyltrimethyl ammonium bromide (CTAB) were bought from Sigma Aldrich (Shanghai) Trading Co., Ltd. $\mathrm{AgNO}_{3}$, ascorbic acid (AA) and $\mathrm{Na}_{2} \mathrm{SO}_{4}$ were acquired from Shanghai Aladdin Bio-Chem Technology Co., Ltd. Nylon 66 filter membrane with the diameter of $13 \mathrm{~mm}$ and the aperture of $0.22 \mu \mathrm{m}$ was bought from Tianjin jinteng Experimental Equipment Co., Ltd. Waters oasis HLB solid phase extraction column with $30 \mathrm{mg}$ of sorbent per Cartridge was purchased from Guangzhou Haien Medical Technology Co., Ltd. Acetone, methanol, hexane, and acetonitrile were obtained from Guangzhou Chemical Regent Factory.

The standard stock solution of NFT and OFX $(50.0 \mathrm{mg} / \mathrm{L})$ was prepared by acetone and $\mathrm{HCl}$ solution $(\mathrm{pH}$ 6.0), respectively. Then, different volumes of standard stock solutions of NFT and OFX were diluted with water to obtain mixed standard solutions of NFT and OFX with different concentrations.

\section{S2 Instruments}

Transmission electron microscope (TEM) images were acquired from FEI Tecnai G2 Spirit 120 kV TEM (FEI, Netherlands). Scanning electron microscope (SEM) images were assessed by Quanta 400F Thermal Field Emission Enviromental SEM (Quanta, Netherlands) and Gemini 500 Field-Emission-SEM (Zeiss/Bruker, Germany). Zeta potentials were collected by EliteSizer multiangle particle size analyzer (Brookhaven, American). X-ray powder diffraction (XRD) patterns were acquired from D8 Advance-XRD (Bruker, Germany) with the scanning range of $5^{\circ} \sim 90^{\circ}$. Fourier transform infrared (FT-IR) spectra were performed by Nicolet iS10 FT-IR spectrophotometer (Thermo Scientific, America) with the wavenumber range of $4000 \sim 500 \mathrm{~cm}^{-1}$. X-ray photoelectron spectra (XPS) were obtained with EscaLab 250Xi spectrometer (Thermo Scientific, America). Ultraviolet visible spectra (UV-vis) were acquired from Shimadzu UV-2600 spectrophotometer (Shimadzu Co., LTD., Japan) with the wavelength range of 200 800 $\mathrm{cm}^{-1}$.

All chromatographic analyses for comparison study were performed by Shimadzu LC-20AB high performance liquid chromatograph with a UV-Vis wavelength detector (HPLC-UV, Shimadzu, Japan). The chromatographic analysis was performed on an Agilent XDB-C18 column $(150 \mathrm{~mm} \times 4.6 \mathrm{~mm}$, i.d. $5 \mu \mathrm{m})$ at $30^{\circ} \mathrm{C}$. The detection wavelength of the UV detector was set at $290 \mathrm{~nm}$. The mixture of methanol (A) and $0.2 \%$ phosphoric acid solution $(\mathrm{B})\left(v_{\mathrm{A}}: v_{\mathrm{B}}=25: 75\right)$ was used as the mobile phase with the flow rate of 0.7 $\mathrm{mL} / \mathrm{min}$.

\section{S3 The details of COMSOL simulation}


For COMSOL simulation, all calculations were operated under a mesh size of $1 \mathrm{~nm}$. The particle size of AgNPs was $30 \mathrm{~nm}$ with the spacing of $2.2 \mathrm{~nm}$. The thickness of $\mathrm{Ti}_{3} \mathrm{C}_{2} \mathrm{~T}_{\mathrm{x}}$ was $2 \mathrm{~nm}$ with the refractive index of 4.59. The excitation wavelength was $785 \mathrm{~nm}$, which was consistent with the wavelength of SERS detection.

\section{S4 The computational details of Materials Studio software}

To understand the electronic properties of $\mathrm{Ti}_{3} \mathrm{C}_{2} \mathrm{~T}_{\mathrm{x}}$ monolayer, eight antibiotics including NFT, furazolidone, furacilin, furaltadone, OFX, pefloxacin, ciprofloxacin, norfloxacin and $\mathrm{Ti}_{3} \mathrm{C}_{2} \mathrm{~T}_{\mathrm{x}}$-antibiotics complexes, density functional theory (DFT) calculations were carried out for their geometry optimizations using the self-consistent charge density-functional tight-binding (SCC-DFTB) ${ }^{1}$ method with a dispersion correction with the DFTB+ $\operatorname{program}^{1,2}$. The smart algorithm ${ }^{3}$ with the force convergence tolerance of 0.05 $\mathrm{kcal} / \mathrm{mol} / \AA$ was used, and the SCC tolerance was set to be $1.0 \times 10^{-5}$ electrons. The crystal cell $(12.392 \times 12.392 \times 80.000)$ of $\mathrm{Ti}_{3} \mathrm{C}_{2} \mathrm{~T}_{\mathrm{x}}$ was constructed, and each antibiotic was put into the cell which was close to the surface of $\mathrm{Ti}_{3} \mathrm{C}_{2} \mathrm{~T}_{\mathrm{x}}$ to construct their interaction model. The interaction energy $\left(\Delta E_{\text {int }}\right)$ was the difference between the total energy of the complex and the sum of total energies of its components.

To evaluate the atomic charge distributions of eight antibiotics and eight antibiotics in the antibiotic/ $\mathrm{Ti}_{3} \mathrm{C}_{2} \mathrm{~T}_{\mathrm{x}}$ complexes, single point calculations based on the optimized geometries were carried out using CASTEP ${ }^{4,5}$. The generalized gradient approximation $(\mathrm{GGA})^{6}$ with the Perdew-Burke-Ernzerh of $(\mathrm{PBE})^{7}$ functional and the Grimme method $^{8,9}$ for DFT-D correction was employed. Besides, a $280.0 \mathrm{eV}$ cut-off energy for the plane-wave basis set was used with the setting $k$-point of $7 \times 7 \times 1$.

\section{S5 The pretreatment process of raw samples}

In this experiment, the aquatic products were purchased from the local markets were fed with NFT and OFX by simulating the process of drug feeding in aquaculture. Firstly, $200.0 \mathrm{mg}$ of NFT or OFX was mixed with $10.0 \mathrm{~g}$ of fish feed to obtain $20.0 \mathrm{mg} / \mathrm{g}$ drug feed. Then, the fish and shrimp samples were fed with 200 mg of NFT or OFX each time, three times a day, for a week. Finally, the edible parts of fish and shrimp were taken out and fully stirred as the raw samples.

In order to obtain the testing solution, the raw sample was pretreated as follows. Firstly, $5.0 \mathrm{~g}$ of raw sample was placed in a centrifuge tube followed by the addition of $5.0 \mathrm{~g}$ anhydrous sodium sulfate and 15.0 $\mathrm{mL}$ acetonitrile. After being mixed well, the centrifuge tube was placed in water bath and ultrasonically extracted for $10 \mathrm{~min}$, followed by being centrifuged at $4000 \mathrm{rpm}$ for $10 \mathrm{~min}$. Then, $15.0 \mathrm{~mL}$ of $\mathrm{n}$-hexane was added into the supernatant to remove the impurity. After n-hexane was removed, the extract was dried under nitrogen blowing. The residue was dissolved in $2.0 \mathrm{~mL}$ of aqueous acetone $\left(v_{\text {aceton }} \cdot v_{\text {water }}=1: 14, \mathrm{pH}=6.0\right)$ and then filtered through $0.22 \mu \mathrm{m}$ membrane to obtain testing solution. 


\section{S6 Optimization of preparation conditions for this substrate}
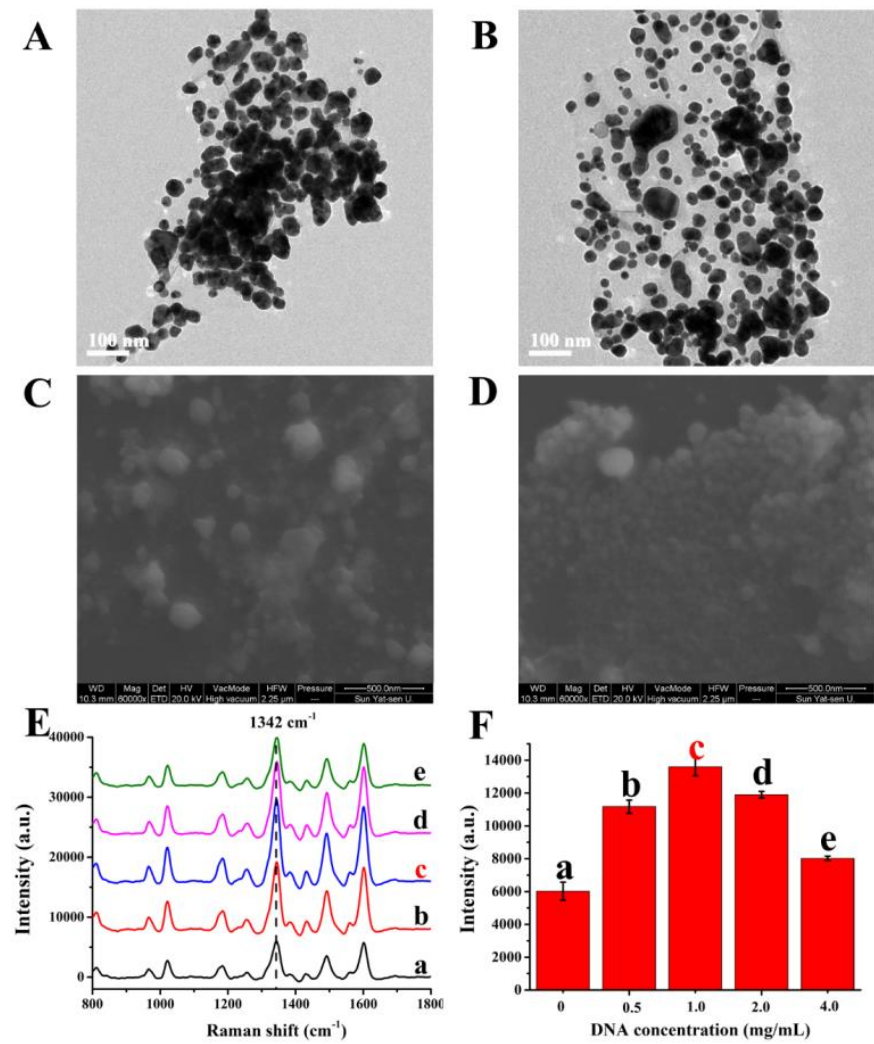

Figure S1 Effect of DNA on the preparation of $\mathrm{Ti}_{3} \mathrm{C}_{2} \mathrm{~T}_{\mathrm{x}} / \mathrm{DNA} / \mathrm{Ag}$ membrane substrates. TEM images (A, B) and SEM images $(C, D)$ of $\mathrm{Ti}_{3} \mathrm{C}_{2} \mathrm{~T}_{\mathrm{x}} / \mathrm{Ag}$ and $\mathrm{Ti}_{3} \mathrm{C}_{2} \mathrm{~T}_{\mathrm{x}} / \mathrm{DNA} / \mathrm{Ag}$ nanocomposites. SERS spectra (E) and the corresponding SERS intensity at $1342 \mathrm{~cm}^{-1}(\mathrm{~F})$ of NFT using the membrane substrate prepared by different concentration of ssDNA solution including (a) 0 , (b) 0.5 , (c) 1.0, (d) 2.0, (e) $4.0 \mathrm{mg} / \mathrm{mL}$, respectively. 


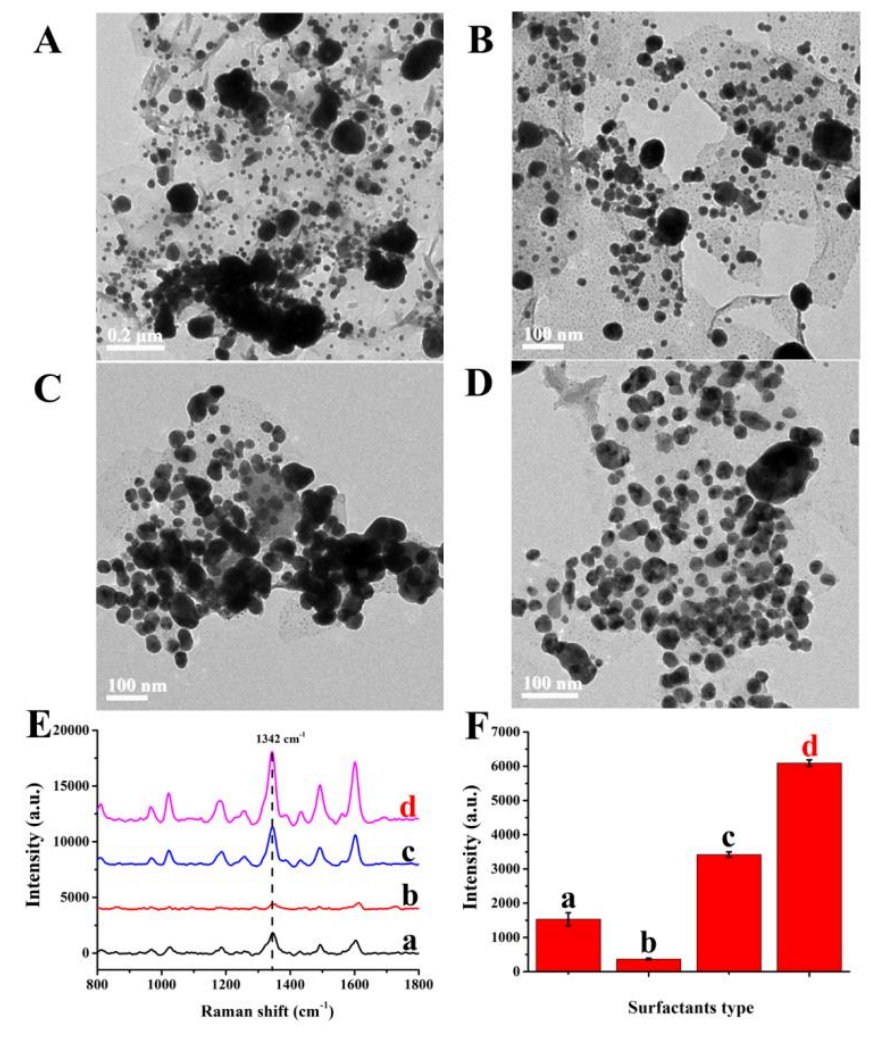

Figure S2 Effect of surfactants type on the preparation of $\mathrm{Ti}_{3} \mathrm{C}_{2} \mathrm{~T}_{\mathrm{x}} / \mathrm{DNA} / \mathrm{Ag}$ membrane substrates. TEM images of $\mathrm{Ti}_{3} \mathrm{C}_{2} \mathrm{~T}_{\mathrm{x}} / \mathrm{DNA} / \mathrm{Ag}$ nanocomposites prepared by different surfactant types, including (A) no surfactant, (B) SDS, (C) CTAB and (D) T-20. SERS spectra (E) and the corresponding SERS intensity at $1342 \mathrm{~cm}^{-1}$ (F) of NFT using the membrane substrates prepared by different surfactant types, including (a) no surfactant, (b) SDS, (c) CTAB and (d) T-20.
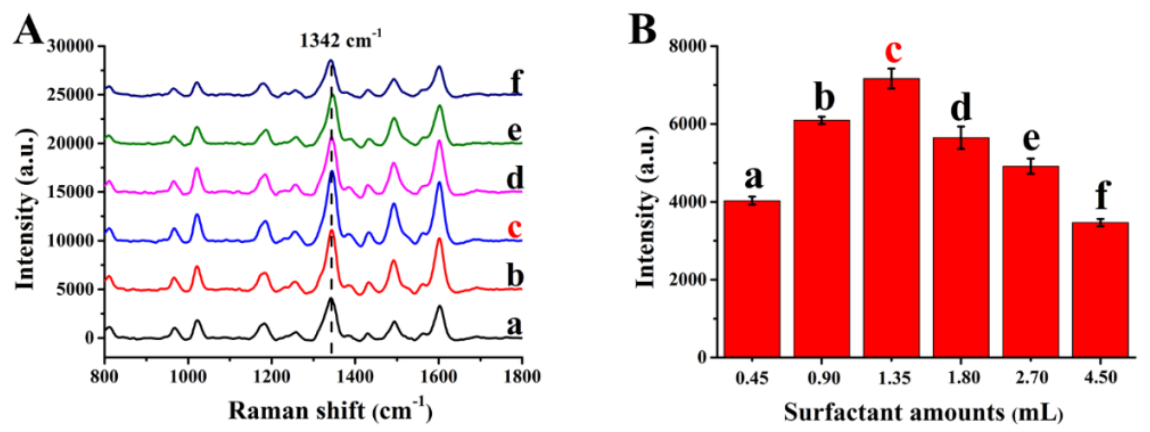

Figure S3 SERS spectra (A) and the corresponding SERS intensity at $1342 \mathrm{~cm}^{-1}$ (B) of NFT using $\operatorname{Ti}_{3} \mathrm{C}_{2} \mathrm{~T}_{\mathrm{x}} / \mathrm{DNA} / \mathrm{Ag}$ membrane substrates prepared by different amounts of 1.0\% T-20 solution including (a)0.45, (b)0.90, (c)1.35, (d)1.80, (e) 2.70 , (f) $4.50 \mathrm{~mL}$, respectively.

$\mathrm{AgNO}_{3}$ concentration would directly affect the formation of AgNPs on the surface of the substrate. In this study, 5.0, 10.0, 20.0 and $40.0 \mathrm{mmol} / \mathrm{L}$ of $\mathrm{AgNO}_{3}$ solutions were selected to prepare $\mathrm{Ti}_{3} \mathrm{C}_{2} \mathrm{~T}_{\mathrm{x}} / \mathrm{DNA} / \mathrm{Ag}$ 
membrane substrates, and NFT was used as the signal molecules for SERS testing. As shown in Figure S4, SERS response increased significantly with the increase of $\mathrm{AgNO}_{3}$ concentration. It was due to the increase of the number and size of AgNPs formed on the surface of substrates, which increased the density of "hot spots" and further enhanced SERS response. When the concentration of $\mathrm{AgNO}_{3}$ was higher than 20.0 mmol/L, the SERS response decreased due to the aggregation of AgNPs formed on the surface of substrates. Therefore, $20.0 \mathrm{mmol} / \mathrm{L}$ was selected as the optimal $\mathrm{AgNO}_{3}$ concentration.
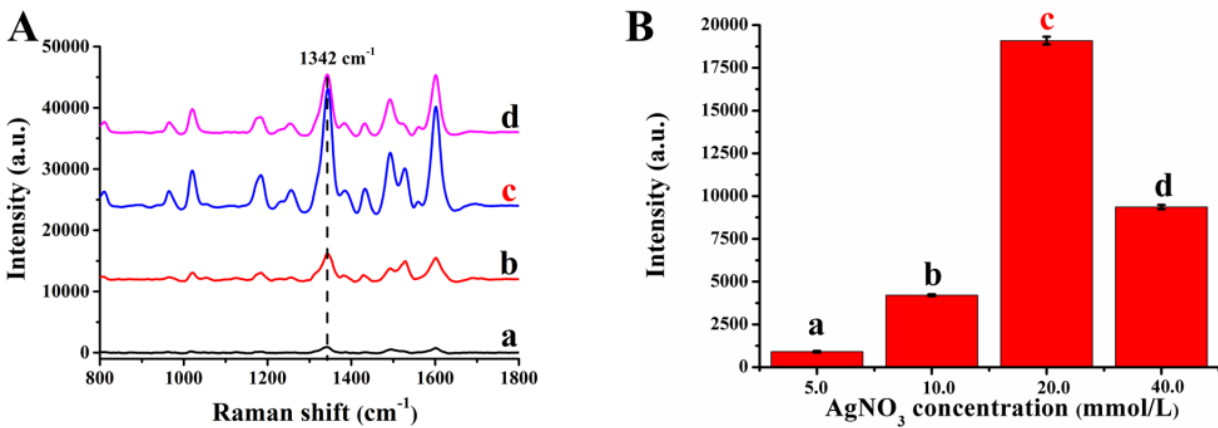

Figure S4 SERS spectra (A) and the corresponding SERS intensity at $1342 \mathrm{~cm}^{-1}$ (B) of NFT using $\mathrm{Ti}_{3} \mathrm{C}_{2} \mathrm{~T}_{\mathrm{x}} / \mathrm{DNA} / \mathrm{Ag}$ membrane substrates prepared by different concentration of $\mathrm{AgNO}_{3}$ solution including (a) 5.0, (b) 10.0, (c) 20.0 and (d) $40.0 \mathrm{mmol} / \mathrm{L}$, respectively.

AA concentration would also affect the formation of AgNPs on the surface of substrates. In this study, 0 , 10.0, 20.0, 30.0 and $40.0 \mathrm{mmol} / \mathrm{L}$ of AA solutions were selected to prepare $\mathrm{Ti}_{3} \mathrm{C}_{2} \mathrm{~T}_{\mathrm{x}} / \mathrm{DNA} / \mathrm{Ag}$ membrane substrates, and NFT was used as the signal molecules for SERS testing. As shown in Figure S5, with the increase of AA concentration, the SERS response was significantly enhanced. The increase of reducing agent concentration caused the increasing number of AgNPs on the substrate surface, resulting in the increase of "hot spot" density and further the increase of SERS response. However, when the concentration of AA was higher than $20.0 \mathrm{mmol} / \mathrm{L}$, the SERS response decreased. This was due to the decrease of AgNPs particle size caused by too fast reduction, which would reduce the number of "hot spot" and lower the SERS response. In addition, it should be noted that even without the addition of reducing agent, the prepared substrate still had a certain SERS response due to the reducing ability of the active groups on the surface of $\mathrm{Ti}_{3} \mathrm{C}_{2} \mathrm{~T}_{\mathrm{x}}$. Therefore, $20.0 \mathrm{mmol} / \mathrm{L}$ was selected as the optimal AA concentration. 
A

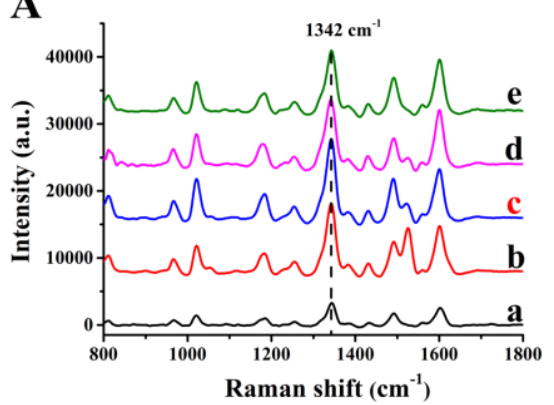

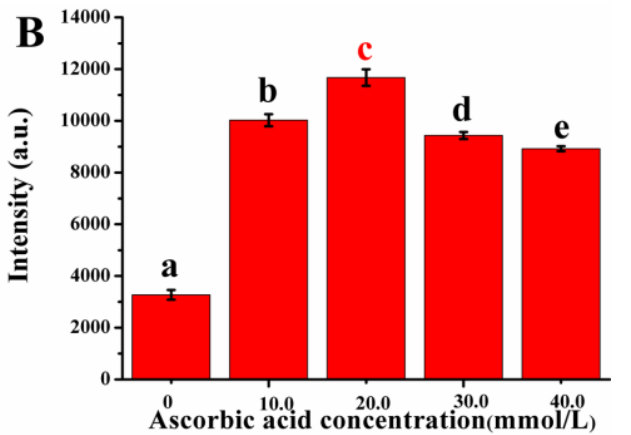

Ascorbic acid concentration(mmol/L)

Figure S5 SERS spectra (A) and the corresponding SERS intensity at $1342 \mathrm{~cm}^{-1}$ (B) of NFT using $\mathrm{Ti}_{3} \mathrm{C}_{2} \mathrm{~T}_{\mathrm{x}} / \mathrm{DNA} / \mathrm{Ag}$ membrane substrates prepared by different concentrations of AA solutions including (a) 0 , (b) 10.0 , (c) 20.0, (d) 30.0 and (e) $40.0 \mathrm{mM}$, respectively.

The membrane loading amount would affect the thickness of the material loaded on the membrane surface. In this experiment, 2.0, 3.0, 4.0, 5.0, 6.0 and $7.0 \mathrm{~mL}$ of $\mathrm{Ti}_{3} \mathrm{C}_{2} \mathrm{~T}_{\mathrm{x}} / \mathrm{DNA} / \mathrm{Ag}$ were respectively loaded on nylon-66 membrane to prepare membrane substrates with different loading amounts, and SERS testing was carried out with NFT as the signal molecule. As shown in Figure S6, with the increase of loading amount, the SERS response was enhanced. Since the increase of materials loaded on the membrane, the gap of nylon-66 filter membrane was filled, resulting in the enhancement of substrate adsorption capacity and "hot spot" density. However, when the loading amount was more than $6.0 \mathrm{~mL}$, the filtration resistance was too large due to the excessive thickness of the material, which would cause membrane damage. Therefore, 6.0 $\mathrm{mL}$ was selected as the optimal loading amount.
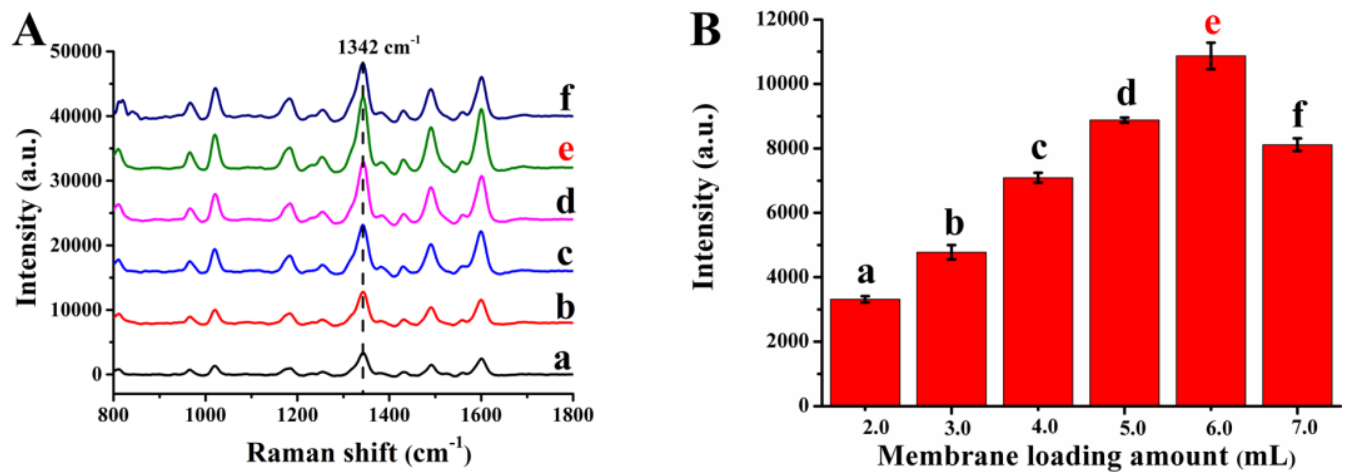

Figure S6 SERS spectra (A) and the corresponding SERS intensity at $1342 \mathrm{~cm}^{-1}$ (B) of NFT using $\mathrm{Ti}_{3} \mathrm{C}_{2} \mathrm{~T}_{\mathrm{x}} / \mathrm{DNA} / \mathrm{Ag}$ membrane substrates prepared by different membrane loading amount including (a) 2.0, (b) 3.0, (c) 4.0, (d) 5.0, (e) 6.0 and (f) $7.0 \mathrm{~mL}$, respectively. 


\section{S7. Characterization of substrates}
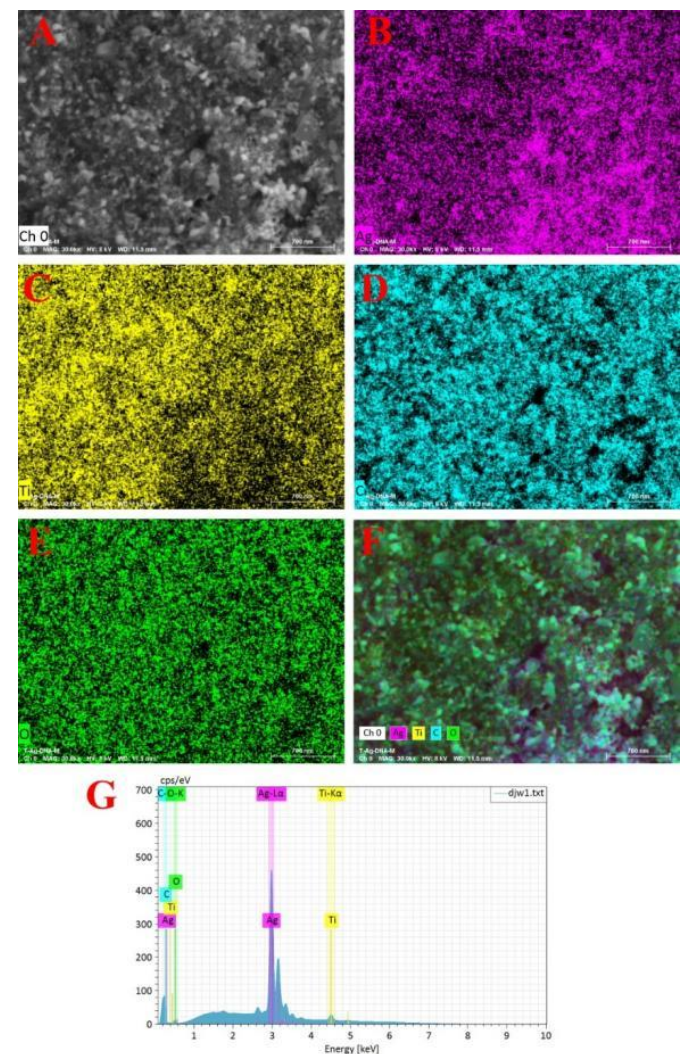

Figure S7 G500 SEM (A) and EDS mapping analysis (G) of $\mathrm{Ti}_{3} \mathrm{C}_{2} \mathrm{~T}_{\mathrm{x}} / \mathrm{DNA} / \mathrm{Ag}$ membrane substrate. The corresponding elements were Ag (B), Ti (C), C (D), O (E) and overlay (F), respectively.

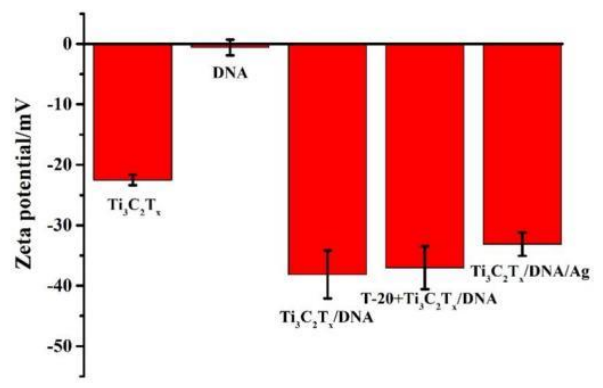

Figure S8 Zeta potential during substrate preparation.

The crystal structures of $\mathrm{Ti}_{3} \mathrm{C}_{2} \mathrm{~T}_{\mathrm{x}}$ nanosheets and $\mathrm{Ti}_{3} \mathrm{C}_{2} \mathrm{~T}_{\mathrm{x}} / \mathrm{DNA} / \mathrm{Ag}$ nanocomposites were characterized by XRD. As shown in Figure S9, the diffraction peaks at $38.2^{\circ}, 44.3^{\circ}$ and $81.6^{\circ}$ were assigned to (lo 008$),\left(\begin{array}{lll}0 & 1\end{array}\right.$ 6), (l $\left.\begin{array}{ll}0 & 2\end{array}\right)$ crystal planes of $\mathrm{Ti}_{3} \mathrm{C}_{2} \mathrm{~T}_{\mathrm{x}}$ crystal $^{10}$, and the diffraction peaks at $64.5^{\circ}$ and $77.4^{\circ}$ were assigned to (2 20 ) and ( $\left.\begin{array}{lll}3 & 1 & 1\end{array}\right)$ crystal planes of Ag nanocrystal (\#04-0783). The results showed that Ag nanocrystals were successfully grown on the surface of $\mathrm{Ti}_{3} \mathrm{C}_{2} \mathrm{~T}_{\mathrm{x}}$, and the crystal structure of the composite remained intact. 


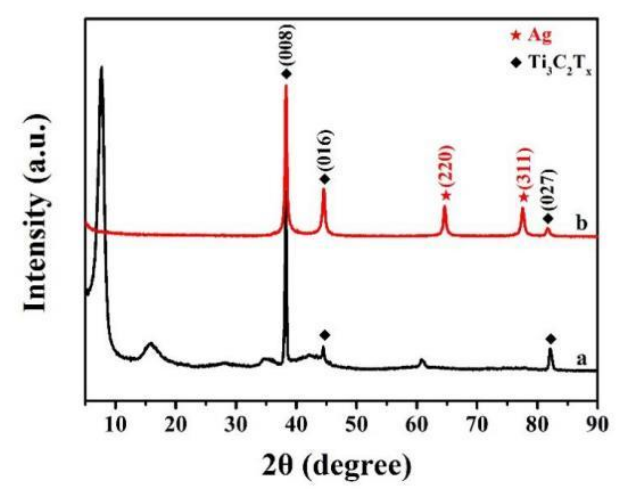

Figure S9 XRD characterization of $\mathrm{Ti}_{3} \mathrm{C}_{2} \mathrm{~T}_{\mathrm{x}}(\mathrm{a})$ and $\mathrm{Ti}_{3} \mathrm{C}_{2} \mathrm{~T}_{\mathrm{x}} / \mathrm{DNA} / \mathrm{Ag}(\mathrm{b})$.

The XPS characterization of $\mathrm{Ti}_{3} \mathrm{C}_{2} \mathrm{~T}_{\mathrm{x}}$ and $\mathrm{Ti}_{3} \mathrm{C}_{2} \mathrm{~T}_{\mathrm{x}} / \mathrm{DNA} / \mathrm{Ag}$ were shown in Figure S10. Compared with $\mathrm{Ti}_{3} \mathrm{C}_{2} \mathrm{~T}_{\mathrm{x}}$, the XPS spectrum of $\mathrm{Ti}_{3} \mathrm{C}_{2} \mathrm{~T}_{\mathrm{x}} / \mathrm{DNA} / \mathrm{Ag}$ showed the presence of $\mathrm{Ag}, \mathrm{N}$ and P elements, in which $\mathrm{N}$ and P elements came from DNA and Ag element came from AgNPs.

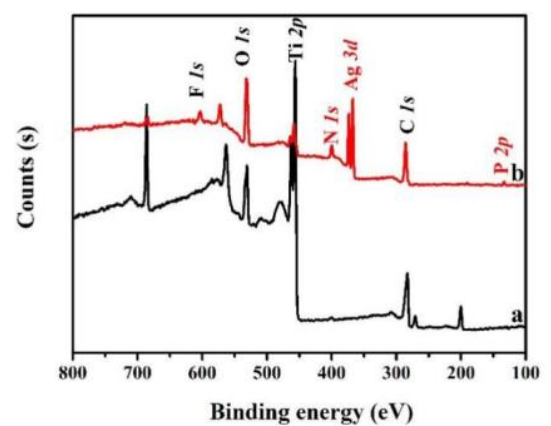

Figure $\mathrm{S10}$ XPS characterization of $\mathrm{Ti}_{3} \mathrm{C}_{2} \mathrm{~T}_{\mathrm{x}}$ (a) and $\mathrm{Ti}_{3} \mathrm{C}_{2} \mathrm{~T}_{\mathrm{x}} / \mathrm{DNA} / \mathrm{Ag}(\mathrm{b})$.

The FT-IR absorption spectra of $\mathrm{Ti}_{3} \mathrm{C}_{2} \mathrm{~T}_{\mathrm{x}}$ and $\mathrm{Ti}_{3} \mathrm{C}_{2} \mathrm{~T}_{\mathrm{x}} / \mathrm{DNA} / \mathrm{Ag}$ were shown in Figure S11. The results showed that the absorption peaks of $\mathrm{Ti}_{3} \mathrm{C}_{2} \mathrm{~T}_{\mathrm{x}} / \mathrm{DNA} / \mathrm{Ag}$ at $3441,1633,1054$ and $535 \mathrm{~cm}^{-1}$ were assigned to $-\mathrm{OH}, \mathrm{C}=\mathrm{O}, \mathrm{C}-\mathrm{O}$ and Ti-O bonds, respectively, which indicated that the structure of $\mathrm{Ti}_{3} \mathrm{C}_{2} \mathrm{~T}_{\mathrm{x}}$ remained intact during the preparation process. ${ }^{11}$

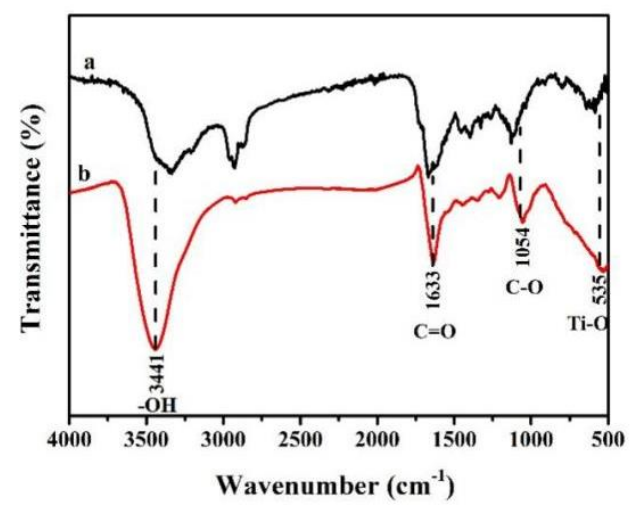

Figure S11 FT-IR characterization of $\mathrm{Ti}_{3} \mathrm{C}_{2} \mathrm{~T}_{\mathrm{x}}$ (a) and $\mathrm{Ti}_{3} \mathrm{C}_{2} \mathrm{~T}_{\mathrm{x}} / \mathrm{DNA} / \mathrm{Ag}(\mathrm{b})$. 
The UV-Vis absorption spectra of $\mathrm{Ti}_{3} \mathrm{C}_{2} \mathrm{~T}_{\mathrm{x}}, \mathrm{Ti}_{3} \mathrm{C}_{2} \mathrm{~T}_{\mathrm{x}} / \mathrm{DNA}$ and $\mathrm{Ti}_{3} \mathrm{C}_{2} \mathrm{~T}_{\mathrm{x}} / \mathrm{DNA} / \mathrm{Ag}$ were shown in Figure $\mathbf{S 1 2}$. The results showed that the absorption peak of DNA modified $\mathrm{Ti}_{3} \mathrm{C}_{2} \mathrm{~T}_{\mathrm{x}}$ did not shift obviously, indicating that DNA would not affect the UV-Vis absorption of $\mathrm{Ti}_{3} \mathrm{C}_{2} \mathrm{~T}_{\mathrm{x}}$. The UV-Vis absorption spectra of $\mathrm{Ti}_{3} \mathrm{C}_{2} \mathrm{~T}_{\mathrm{x}}$ and $\mathrm{Ti}_{3} \mathrm{C}_{2} \mathrm{~T}_{\mathrm{x}} / \mathrm{DNA}$ showed a strong absorption peak around $319 \mathrm{~nm}$ and a wide absorption peak around $762 \mathrm{~nm}$, which might be due to the inter band transition caused by the surface terminations ${ }^{10}$. Then, due to the successful growth of AgNPs, the maximum absorption peak of $\mathrm{Ti}_{3} \mathrm{C}_{2} \mathrm{~T}_{\mathrm{x}} / \mathrm{DNA} / \mathrm{Ag}$ shifted to $454 \mathrm{~nm}$

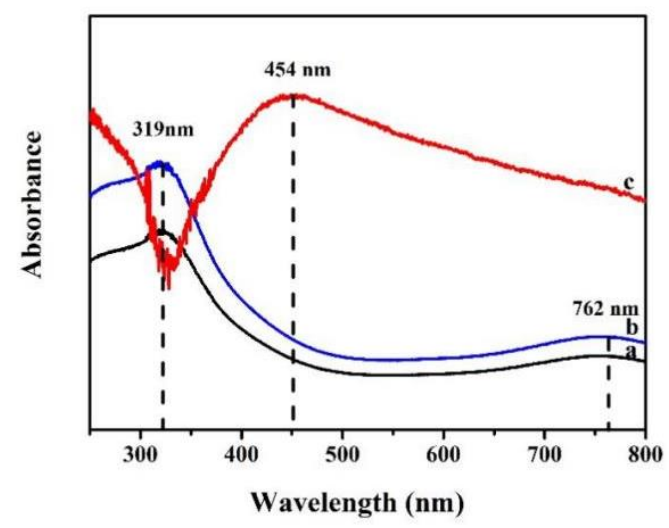

Figure S12 UV-Vis characterization of $\mathrm{Ti}_{3} \mathrm{C}_{2} \mathrm{~T}_{\mathrm{x}}(\mathrm{a}), \mathrm{Ti}_{3} \mathrm{C}_{2} \mathrm{~T}_{\mathrm{x}} / \mathrm{DNA}$ (b) and $\mathrm{Ti}_{3} \mathrm{C}_{2} \mathrm{~T}_{\mathrm{x}} / \mathrm{DNA} / \mathrm{Ag}$ (c), respectively.

\section{S8 Reproducibility, stability and SERS activity of this substrate}
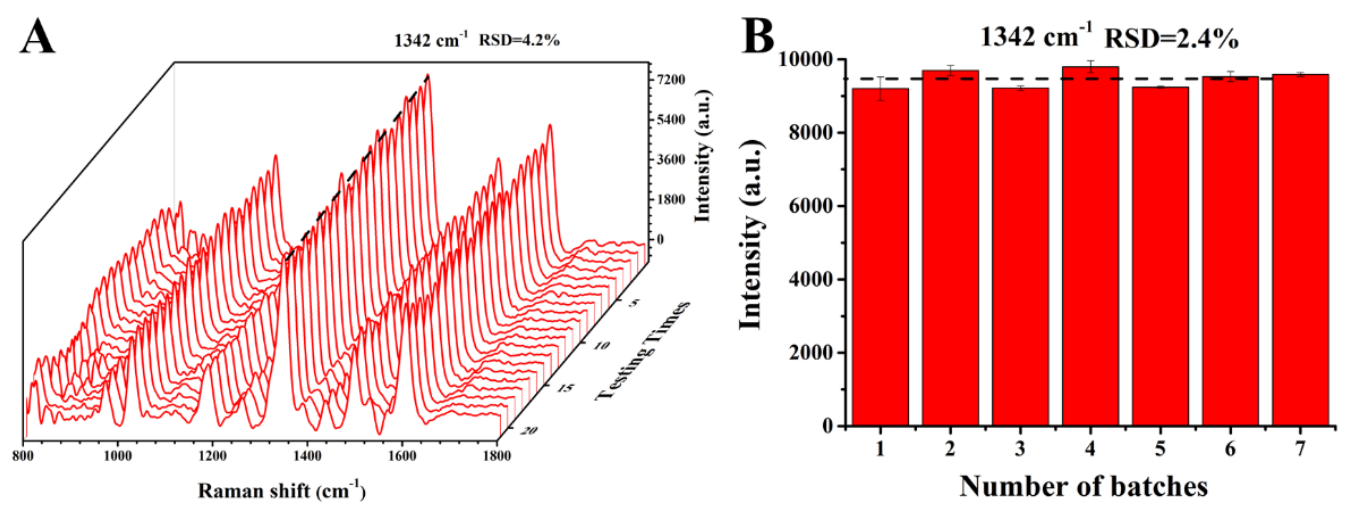

Figure S13 SERS spectra of NFT at different positions $(n=21)$ of the same membrane substrate (A). SERS intensity at $1342 \mathrm{~cm}^{-1}$ of NFT on different batches $(\mathrm{n}=7)$ of membrane substrates (B). The tested solution was $8.0 \mathrm{mg} / \mathrm{L}$ of NFT solution. 
A
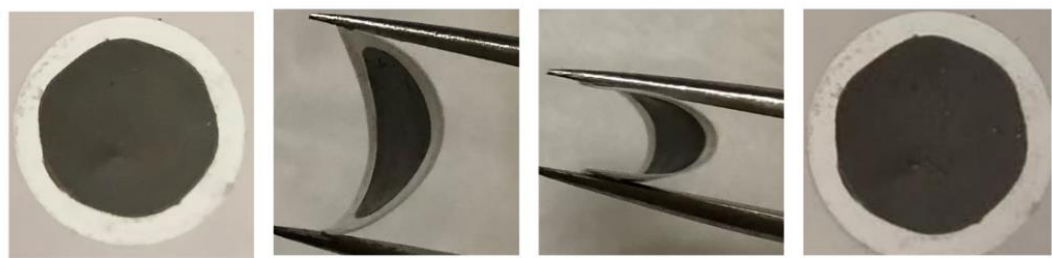

B

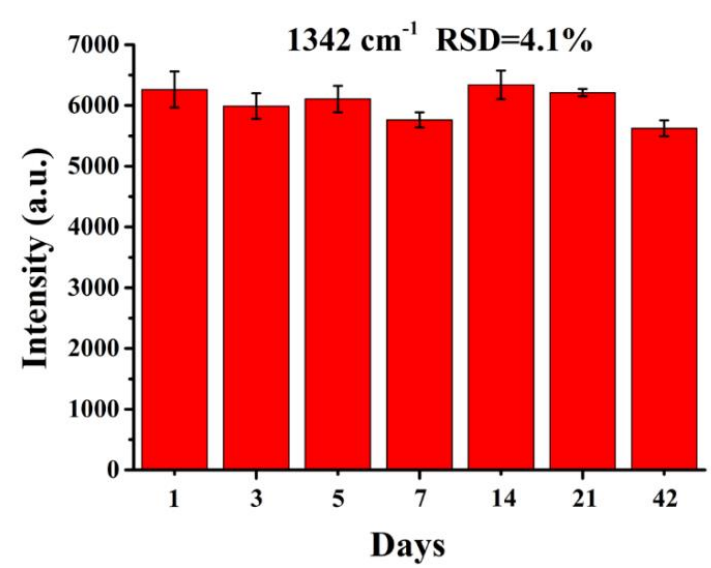

Figure S14 Stability of $\mathrm{Ti}_{3} \mathrm{C}_{2} \mathrm{~T}_{\mathrm{x}} / \mathrm{DNA} / \mathrm{Ag}$ membrane substrates. The state of membrane after different bending treatments (A). SERS intensity at $1342 \mathrm{~cm}^{-1}$ of NFT using $\mathrm{Ti}_{3} \mathrm{C}_{2} \mathrm{~T}_{\mathrm{x}} / \mathrm{DNA} / \mathrm{Ag}$ membranes after being stored for different days (B).

The testing solution was $5.0 \mathrm{mg} / \mathrm{L}$ NFT solution.

For the preparation of $50 \mathrm{~nm} \mathrm{Ag}$ sol substrate, $18.0 \mathrm{mg} \mathrm{AgNO}_{3}$ was firstly dissolved in $100 \mathrm{ml}$ deionized water, and then heated to boiling in $135^{\circ} \mathrm{C}$ oil bath. After that, $3.0 \mathrm{~mL}$ of $1.0 \%$ sodium citrate solution was rapidly added to the solution, and heated for $1 \mathrm{~h}$ under stirring reflux. After the reaction, the silver sol was obtained by being naturally cooled down to room temperature and stored at $4{ }^{\circ} \mathrm{C}$. The comparison of 8.0 $\mathrm{mg} / \mathrm{L} \mathrm{NFT}$ and $5.0 \mathrm{mg} / \mathrm{L}$ OFX detection with no substrate, $50 \mathrm{~nm} \mathrm{Ag}$ sol substrate and $\mathrm{Ti}_{3} \mathrm{C}_{2} \mathrm{~T}_{\mathrm{x}} / \mathrm{DNA} / \mathrm{Ag}$ membrane substrate were shown in Figure S15.
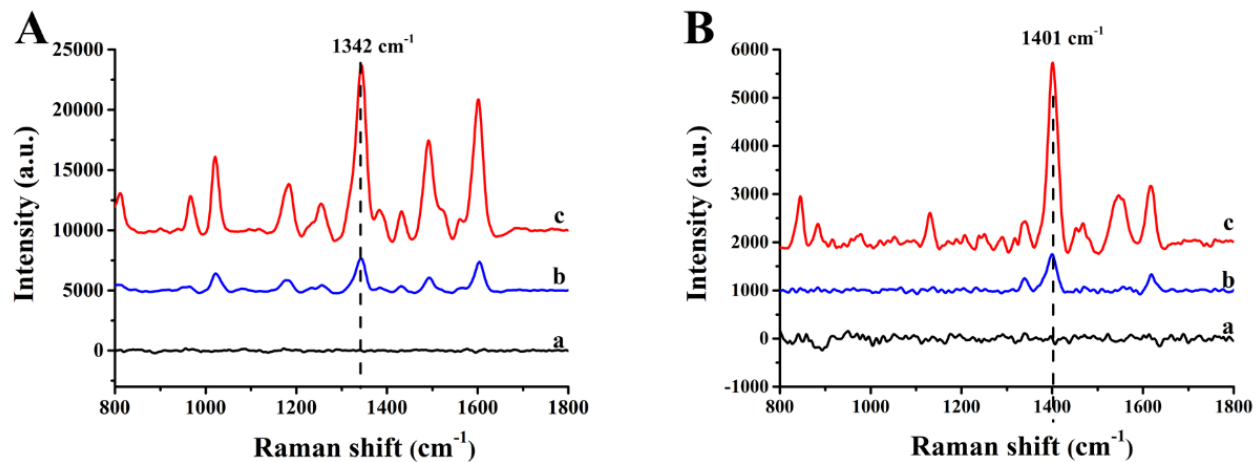

Figure S15 SERS spectra of NFT (A) and OFX (B) on Si plate (a), Ag sol substrate (b) and membrane substrate (c). The concentrations of NFT and OFX were $8.0 \mathrm{mg} / \mathrm{L}$ and $5.0 \mathrm{mg} / \mathrm{L}$, respectively. 


\section{S9 Study on the adsorption and enrichment performance of this substrate}

In order to verify the adsorption and enrichment capacity of $\mathrm{Ti}_{3} \mathrm{C}_{2} \mathrm{~T}_{\mathrm{x}} / \mathrm{DNA} / \mathrm{Ag}$ membrane substrate, the changes of UV-Vis absorption peak intensity of $1.0 \mathrm{mg} / \mathrm{L}$ NFT solution and OFX solution before and after filtration by the membrane substrate and nylon-66 filter membrane were tested. As shown in Figure S16, the intensity of NFT and OFX decreased significantly after filtration by the membrane substrate, while their intensity did not change significantly after filtration by the nylon-66 membrane. The result suggested that $\mathrm{Ti}_{3} \mathrm{C}_{2} \mathrm{~T}_{\mathrm{x}} / \mathrm{DNA} / \mathrm{Ag}$ membrane substrate had good adsorption and enrichment capability for NFT and OFX.
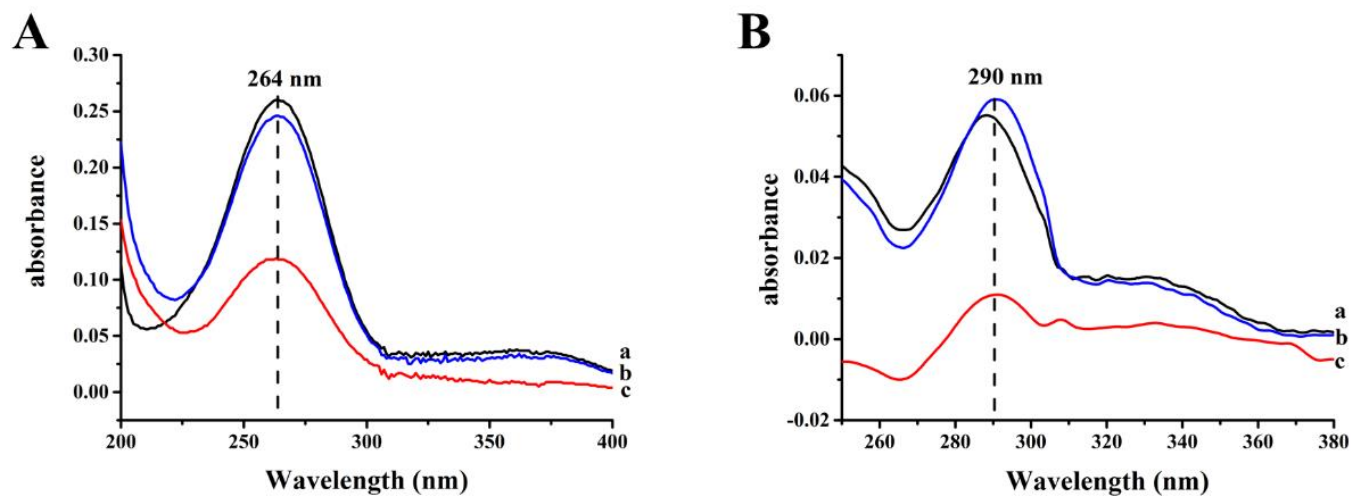

Figure S16 UV-Vis spectra of NFT (A) and OFX (B) before filtration (a), after filtration with nylon-66 membrane (b), and after filtration with membrane substrate (c).

\section{S10 Calculation of enhancement factor}

Enhancement factor (EF) was calculated by using the following equation ${ }^{12}$,

$$
E F=\frac{l_{\text {SERS }}}{l_{\text {Raman }}} \times \frac{C_{\text {Raman }}}{C_{\text {SERS }}}
$$

where $I_{S E R S}$ referred to SERS intensity of characteristic peak of targets on $\mathrm{Ti}_{3} \mathrm{C}_{2} \mathrm{~T}_{\mathrm{x}} / \mathrm{DNA} / \mathrm{Ag}$ membrane substrate, and $I_{\text {Raman }}$ represented Raman intensity of characteristic peak of targets on $\mathrm{Si}$ plate. The concentrations of targets on $\mathrm{Ti}_{3} \mathrm{C}_{2} \mathrm{~T}_{\mathrm{x}} / \mathrm{DNA} / \mathrm{Ag}$ membrane substrate and Si plate were served as $C_{\text {SERS }}$ and $C_{\text {Raman }}$, respectively. The characteristic peak at $1342 \mathrm{~cm}^{-1}$ of NFT and 1401 $\mathrm{cm}^{-1}$ of OFX was selected for calculation. The corresponding SERS and Raman spectra were shown in Figure S17. According to Eq. (1), the EFs of $\mathrm{Ti}_{3} \mathrm{C}_{2} \mathrm{~T}_{\mathrm{x}} / \mathrm{DNA} / \mathrm{Ag}$ membrane substrates to NFT and OFX were calculated as $1.0 \times 10^{5}$ and $2.9 \times 10^{5}$ in this work, respectively. 

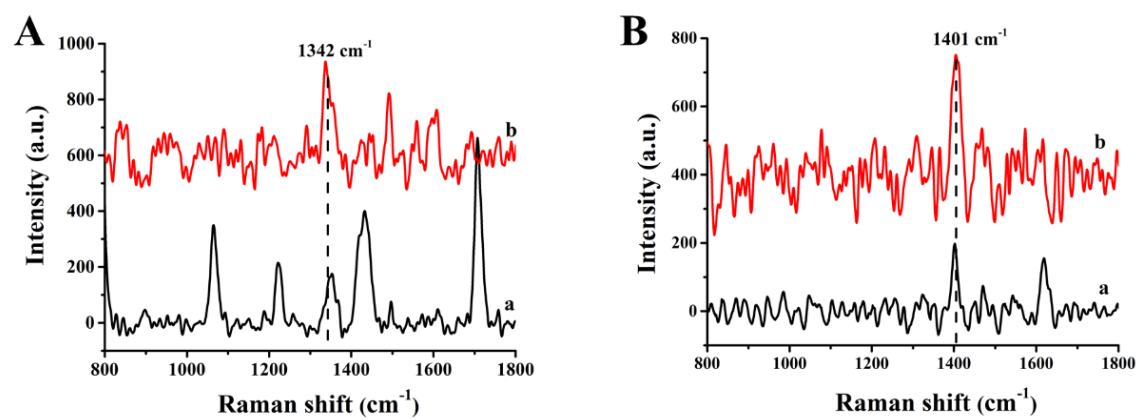

Figure S17 (A) The comparison between Raman spectrum of 1.0 g/L NFT solution (a) and SERS spectrum of $20.0 \mu \mathrm{g} / \mathrm{L}$ NFT solution (b). (B) The comparison between Raman spectrum of $10.0 \mathrm{~g} / \mathrm{L}$ OFX solution (a) and SERS spectrum of $60.0 \mu \mathrm{g} / \mathrm{L}$ OFX solution (b).

S11 Study of the CM effect of this substrate

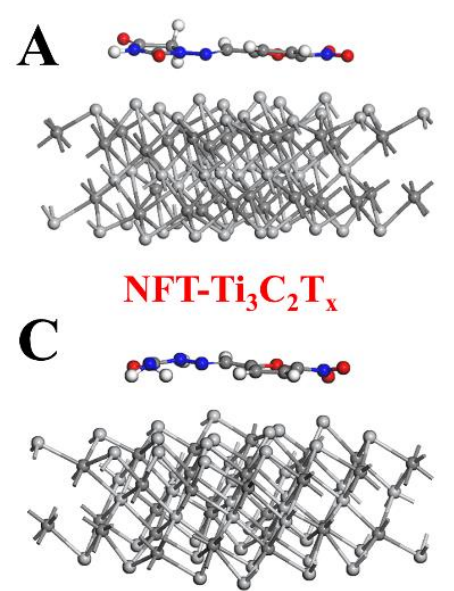

Furacilin- $\mathbf{T i}_{3} \mathrm{C}_{2} \mathbf{T}_{\mathbf{x}}$
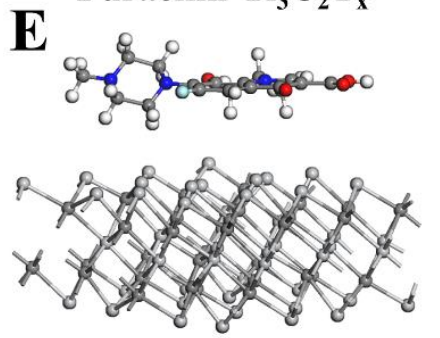

$\mathrm{OFX}-\mathrm{Ti}_{3} \mathrm{C}_{2} \mathrm{~T}_{\mathrm{x}}$

G
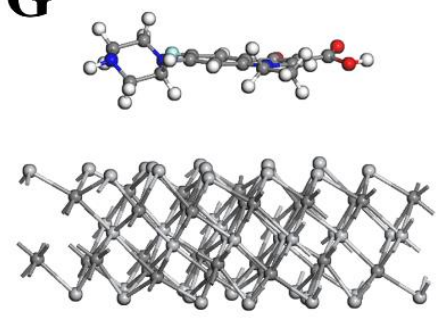

Ciprofloxacin- $\mathrm{Ti}_{3} \mathrm{C}_{2} \mathbf{T}_{\mathrm{x}}$
$\mathbf{B}$

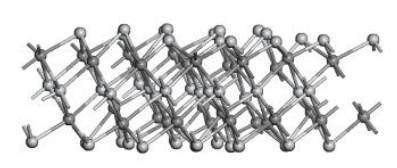

Furazolidone- $\mathrm{Ti}_{3} \mathrm{C}_{2} \mathrm{~T}_{\mathrm{x}}$
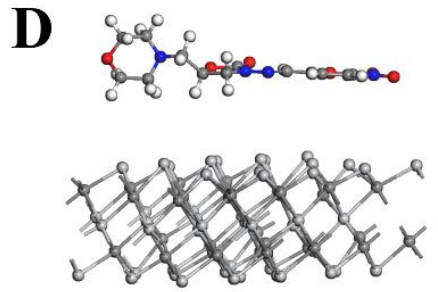

$\mathbf{F}$
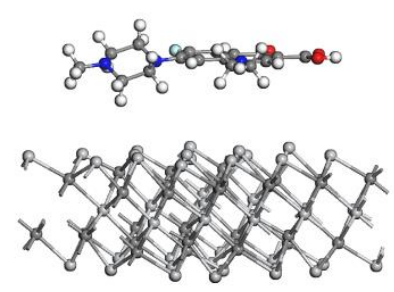

Pefloxacin- $\mathrm{Ti}_{3} \mathrm{C}_{2} \mathrm{~T}_{\mathrm{x}}$

$\mathbf{H}$
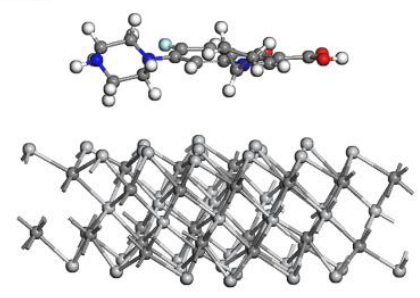

Norfloxacin- $\mathrm{Ti}_{3} \mathrm{C}_{2} \mathrm{~T}_{\mathrm{x}}$

Figure S18 Interaction models between $\mathrm{Ti}_{3} \mathrm{C}_{2} \mathrm{~T}_{\mathrm{x}}$ and different antibiotics, including NFT (A), furazolidone (B), furacilin (C), furaltadone (D), OFX (E), pefloxacin (F), ciprofloxacin (G) and norfloxacin (H). 


\section{S12 Simultaneous quantification for trace NFT and OFX in aquatic samples by SERS}

In order to obtain good SERS quantification performance, the pretreatment conditions of samples such as extraction solvent, ultrasonic time and $\mathrm{pH}$ value, and the SERS analysis conditions such as integration time, laser wavelength, laser intensity and sample volume were optimized. The optimized sample pretreatment conditions were as follows: extraction solvent, acetonitrile; ultrasonic time, $10 \mathrm{~min}$; and $\mathrm{pH}$ value, 6.0. The optimized SERS analysis conditions were as follows: integration time, 3s; laser wavelength, $785 \mathrm{~nm}$; laser intensity, $48 \mathrm{~mW}$; and sample volume, $2.0 \mathrm{~mL}$.

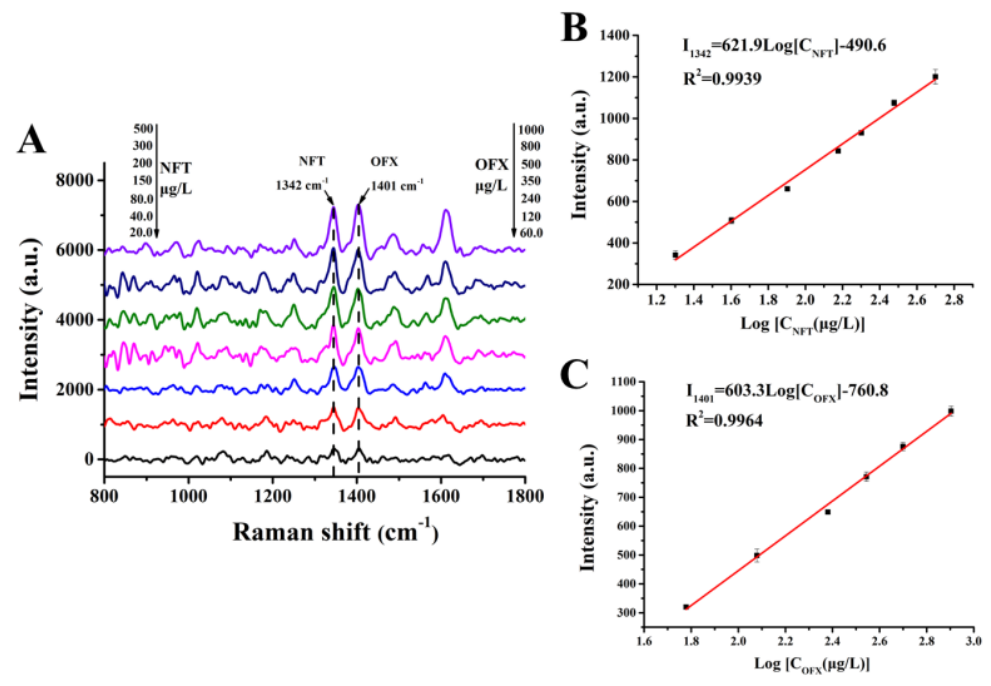

Figure S19 SERS spectra of different concentrations of NFT and OFX mixed standard solution on membrane substrate (A). Standard curve and linear equation for simultaneous SERS quantification of NFT (B) and OFX (C).

Table S1 Typical SERS peaks for NFT and OFX

\begin{tabular}{|c|c|c|c|}
\hline Targets & SERS shift $/ \mathrm{cm}^{-1}$ & Peak assignment* & Ref. \\
\hline \multirow{4}{*}{ NFT } & 1021 & $v(\mathrm{C}-\mathrm{O}), v(\mathrm{C}-\mathrm{C})$ & \multirow{4}{*}{13} \\
\hline & 1342 & $\omega(\mathrm{H}-\mathrm{C}-\mathrm{H})$, vs(ring) & \\
\hline & 1491 & $v($ ring) in-plane & \\
\hline & 1601 & $v(\mathrm{C}=\mathrm{N})$ in-plane symmetric stretch & \\
\hline \multirow{4}{*}{ OFX } & 1401 & $v \mathrm{~s}\left(\mathrm{COO}^{-}\right)$ & \multirow{4}{*}{14} \\
\hline & 1465 & $v s(\mathrm{C}-\mathrm{N}-\mathrm{H})$ ring & \\
\hline & 1553 & $v(\mathrm{C}-\mathrm{O})$ & \\
\hline & 1616 & $v(\mathrm{C}=\mathrm{C}) \mathrm{b}$ & \\
\hline
\end{tabular}

* Abbreviations: "v", stretching vibration; " $\omega$ ", wagging vibration; "s", symmetric vibration; "ring”, ring skeleton; "b", benzene ring 
Table S2 Comparison of different methods for determination of NFT and OFX

\begin{tabular}{|c|c|c|c|c|c|c|}
\hline Method & Sample & Target & $\begin{array}{c}\text { Linear range } \\
(\mathrm{mg} / \mathrm{L})\end{array}$ & $\begin{array}{l}\text { LOD } \\
(\mathrm{mg} / \mathrm{L})\end{array}$ & $\begin{array}{c}\text { Recovery } \\
(\%)\end{array}$ & Ref. \\
\hline HPLC-DAD & Animal feeds & NFT & $1.0 \sim 130 \times 10^{-3}$ & $0.26 \times 10^{-3}$ & 79.2 93.2 & 15 \\
\hline LC-MS & Feed waters & NFT & $0.2 \sim 1.4 \times 10^{-3}$ & $0.04 \times 10^{-3}$ & $97.6 \sim 106$ & 16 \\
\hline Fluorescence & Fishes & NFT & $0.16 \sim 1.84$ & 0.015 & $90.8 \sim 106$ & 17 \\
\hline SERS & Duck meats & NFT & $0.05 \sim 10$ & 0.05 & $98.1 \sim 106$ & 18 \\
\hline SERS & Cosmetics & NFT & $0.5 \sim 10$ & 0.05 & $86.8 \sim 106$ & 19 \\
\hline SERS & $\begin{array}{c}\text { Fish feed and } \\
\text { aquatic } \\
\text { samples }\end{array}$ & NFT & $0.050 \sim 1.0$ & 0.014 & $81.9 \sim 116.3$ & 20 \\
\hline HPLC-FLD & Shrimps & OFX & $3 \sim 1500 \times 10^{-3}$ & $1 \times 10^{-3}$ & 84 & 21 \\
\hline HPLC-CL & prawns & OFX & $0.5 \sim 250 \times 10^{-3}$ & $0.43 \times 10^{-3}$ & $88.3 \sim 101$ & 22 \\
\hline SERS & Eye drops & OFX & $0.010 \sim 1000$ & 0.010 & $96.9 \sim 107$ & 23 \\
\hline SERS & $\begin{array}{l}\text { Tablet and } \\
\text { eye drops }\end{array}$ & OFX & $0.10 \sim 0.50$ & 0.024 & 98.6 99.7 & 24 \\
\hline SERS & Duck meats & OFX & $0.05 \sim 10.0$ & 0.05 & $89 \sim 106$ & 25 \\
\hline SERS & $\begin{array}{l}\text { Aquatic } \\
\text { samples }\end{array}$ & $\begin{array}{l}\text { NFT } \\
\text { OFX }\end{array}$ & $\begin{array}{l}0.020 \sim 0.50 \\
0.060 \sim 0.80\end{array}$ & 0.012 & $\begin{array}{l}91.7 \sim 106 \\
88.0 \sim 107\end{array}$ & This work \\
\hline
\end{tabular}


Table S3 Simultaneous quantification of trace NFT and OFX in aquatic samples by SERS ( $\mathrm{n}=3$ )

\begin{tabular}{|c|c|c|c|c|c|c|c|}
\hline \multirow[b]{2}{*}{ Sample } & \multirow[b]{2}{*}{ Target } & \multicolumn{4}{|c|}{ SERS method } & \multirow{2}{*}{$\begin{array}{c}\text { HPLC } \\
\text { method } \\
(\mu \mathrm{g} / \mathrm{kg})\end{array}$} & \multirow{2}{*}{$\begin{array}{c}\text { Relative } \\
\text { error } \\
(\%)^{a}\end{array}$} \\
\hline & & $\begin{array}{c}\text { Detected } \\
(\mu \mathrm{g} / \mathrm{kg})\end{array}$ & $\begin{array}{c}\text { Added } \\
(\mu \mathrm{g} / \mathbf{k g})\end{array}$ & $\begin{array}{c}\text { Recovery } \\
(\%)\end{array}$ & $\begin{array}{l}\text { RSD } \\
(\%) \\
\end{array}$ & & \\
\hline \multirow{2}{*}{ Fish 1} & NFT & N.D. ${ }^{b}$ & $\begin{array}{l}1 \\
1\end{array}$ & $\begin{array}{l}1 \\
1\end{array}$ & $\begin{array}{l}1 \\
1\end{array}$ & N.D. & I \\
\hline & OFX & $49.1( \pm 0.5)$ & $\begin{array}{l}40.0 \\
80.0 \\
\end{array}$ & $\begin{array}{r}105 \\
91.4 \\
\end{array}$ & $\begin{array}{l}1.8 \\
2.3 \\
\end{array}$ & $46.6( \pm 1.2)$ & 5.3 \\
\hline \multirow{2}{*}{ Fish 2} & NFT & $13.7( \pm 0.2)$ & $\begin{array}{l}12.0 \\
24.0\end{array}$ & $\begin{array}{l}94.8 \\
95.0\end{array}$ & $\begin{array}{l}0.8 \\
0.3\end{array}$ & $15.2( \pm 0.5)$ & -9.8 \\
\hline & OFX & N.D. & $\begin{array}{l}1 \\
1\end{array}$ & $\begin{array}{l}1 \\
1\end{array}$ & $\begin{array}{l}1 \\
1\end{array}$ & N.D. & I \\
\hline \multirow{2}{*}{ Fish 3} & NFT & $8.0( \pm 0.8)$ & $\begin{array}{r}8.0 \\
16.0\end{array}$ & $\begin{array}{r}103 \\
91.7\end{array}$ & $\begin{array}{l}3.5 \\
2.1\end{array}$ & $7.8( \pm 0.3)$ & 2.7 \\
\hline & OFX & $42.6( \pm 5.1)$ & $\begin{array}{l}20.0 \\
40.0\end{array}$ & $\begin{array}{l}106 \\
107\end{array}$ & $\begin{array}{l}5.5 \\
4.1\end{array}$ & $40.5( \pm 0.8)$ & 5.3 \\
\hline \multirow{2}{*}{$\begin{array}{c}\text { Shrimp } \\
1\end{array}$} & NFT & N.D. & $\begin{array}{l}80.0 \\
200\end{array}$ & $\begin{array}{r}106 \\
94.3\end{array}$ & $\begin{array}{l}1.1 \\
2.5\end{array}$ & N.D. & I \\
\hline & OFX & N.D. & $\begin{array}{l}100 \\
250\end{array}$ & $\begin{array}{l}88.0 \\
94.6\end{array}$ & $\begin{array}{l}4.4 \\
2.9\end{array}$ & N.D. & I \\
\hline
\end{tabular}

${ }^{a}$ Relative error of SERS and HPLC method $\quad{ }^{b}$ N.D.=not detected 


\section{References}

(1) Elstner, M.; Porezag, D.; Jungnickel, G.; Elsner, J.; Haugk, M.; Frauenheim, T.; Suhai, S.; Seifert, G. Self-consistent-charge density-functional tight-binding method for simulations of complex materials properties. Phys. Rev. B 1998, 58, 7260-7268.

(2) Elstner, M.; Hobza, P.; Frauenheim, T.; Suhai, S.; Kaxiras, E. Hydrogen bonding and stacking interactions of nucleic acid base pairs: A densityfunctional-theory based treatment. J. Chem. Phys. 2001, 114, 5149-5155.

(3) Amer, M. S.; Elliott, J. A.; Maguire, J. F.; Windle, A. H. Calculations of the Raman spectra of C60 interacting with water molecules. Chem. Phys. Lett. 2005, 411, 395-398.

(4) Milman, V.; Winkler, B.; White, J. A.; Pickard, C. J.; Payne, M. C.; Akhmatskaya, E. V.; Nobes, R. H. Electronic structure, properties, and phase stability of inorganic crystals: a pseudopotential plane-wave study. Int. J. Quantum. Chem. 2000, 77, 895-910.

(5) Payne, M. C.; Arias, T. A.; Joannopoulos, J. D. J. R. o. M. P. Iterative minimization techniques for ab initio total-energy calculations: molecular dynamics and conjugate gradients. Rev. Mod. Phys. 1992, 64, 1045-1097.

(6) Johnson, R. A.; White, P. J. J. P. R. B. C. M. Computation for surface energies and displacements using empirical interatomic forces. Phys. Rev. B 1976, 13, 5293-5302.

(7) Perdew, J.; Burke, K.; Ernzerhof, M. Generalized Gradient Approximation Made Simple. Phys. Rev. Lett. 1996, 77 , 3865-3868.

(8) Grimme, S.; Antony, J.; Ehrlich, S.; Krieg, H. A consistent and accurate ab initio parametrization of density functional dispersion correction (DFT-D) for the 94 elements H-Pu. J. Chem. Phys. 2010, 132, 154104-15424.

(9) Grimme, S. Semiempirical GGA-type density functional constructed with a long-range dispersion correction. $J$. Computat. Chem. 2006, 27, 1787-1799.

(10) Liu, R.; Jiang, L.; Lu, C.; Yu, Z.; Li, F.; Jing, X.; Xu, R.; Zhou, W.; Jin, S. Large-scale two-dimensional titanium carbide MXene as SERS-active substrate for reliable and sensitive detection of organic pollutants. Spectrochim. Acta A 2020, 236, 118336.

(11) Du, X.; Qu, J.; Deng, S.; Du, Z.; Cheng, X.; Wang, H. Tis $\mathrm{C}_{2} \mathrm{~T}_{\mathrm{x}} @ \mathrm{PDA}$-integrated polyurethane phase change composites with superior solar-thermal conversion efficiency and improved thermal conductivity. ACS Sustain. Chem. Eng. 2020, 8, 5799-5806

(12) Kim, W. S.; Shin, J. H.; Park, H. K.; Choi, S. A low-cost, monometallic, surface-enhanced Raman scattering-functionalized paper platform for spot-on bioassays. Sensor. Actuat. B-Chem. 2016, 222, 1112-1118.

(13) Wu, Y. P.; Liu, Y.; Tang, X. F.; Cheng, Z. Z.; Liu, H. L. Tunable plasmonics of hollow raspberry-like nanogold for the robust Raman scattering detection of antibiotics on a portable Raman spectrometer. Analyst 2020, 145, 5854-5860.

(14) El-Zahry, M. R.; Lendl, B. Structure elucidation and degradation kinetic study of Ofloxacin using surface enhanced Raman spectroscopy. Spectrochim. Acta A 2018, 193, 63-70.

(15) Vinas, P.; Campillo, N.; Carrasco, L.; Hernandez-Cordoba, M. Analysis of nitrofuran residues in animal feed using liquid chromatography and photodiode-array detection. Chromatographia 2007, 65, 85-89.

(16) Ardsoongnearn, C.; Boonbanlu, O.; Kittijaruwattana, S.; Suntornsuk, L. Liquid chromatography and ion trap mass spectrometry for simultaneous and multiclass analysis of antimicrobial residues in feed water. J. Chromatogr. B 2014, 945 , $31-38$. 
(17) Ni, Y. N.; Gu, Y.; Kokot, S. Multiway calibrations based on spectrofluorimetric data derived from kinetic analysis of the hydrolysis reaction of nitrofurans-a comparison of prediction performance. Chemometr. Intell. Lab. 2012, 112, 55-64.

(18) Wu, Y. P.; Liu, Y.; Tang, X. F.; Cheng, Z. Z.; Liu, H. L. Tunable plasmonics of hollow raspberry-like nanogold for the robust Raman scattering detection of antibiotics on a portable Raman spectrometer. Analyst 2020, 145, 5854-5860.

(19) Zhang, Y.; Yu, Z.; Yue, Z.; Gao, J.; Wu, S.; Zhang, Z.; Li, G. Rapid determination of trace nitrofurantoin in cosmetics by surface enhanced Raman spectroscopy using nanoarrayed hydroxyl polystyrene-based substrate. J. Raman Spectrosc. 2019, 50 (8), 1094-1102.

(20) Zhang, H.; Lai, H.; Wu, X.; Li, G.; Hu, Y. $\mathrm{CoFe}_{2} \mathrm{O}_{4} @ \mathrm{HNTs} / \mathrm{AuNPs}$ substrate for rapid magnetic solid-phase extraction and efficient SERS detection of complex samples all-in one. Anal. Chem. 2020, 92, 4607-4613.

(21) Pochivalov, A.; Timofeeva, I.; Vakh, C.; Bulatov, A. Switchable hydrophilicity solvent membrane-based microextraction: HPLC-FLD determination of fluoroquinolones in shrimps. Anal. Chim. Acta 2017, 976, 35-44.

(22) Wan, G. H.; Cui, H.; Pan, Y. L.; Zheng, P.; Liu, L. J. Determination of quinolones residues in prawn using high-performance liquid chromatography with $\mathrm{Ce}(\mathrm{IV})-\mathrm{Ru}(\mathrm{bpy}) 3^{2+}-\mathrm{HNO}_{3}$ chemiluminescence detection. $J$. Chromatogra. B 2006, 843, 1-9.

(23) He, Y.; Li, L.; Li, X.; Zhang, J. Preparation of Magnetic Molecularly Imprinted Polymer $\mathrm{Fe}_{3} \mathrm{O}_{4} @ \mathrm{SiO}_{2} @ \mathrm{Ag}-\mathrm{MIPs}$ and Its Identification and SERS Detection of Ofloxacin. Chem. Lett. 2020, 49, 713-716.

(24) El-Zahry, M. R.; Lendl, B. Structure elucidation and degradation kinetic study of Ofloxacin using surface enhanced Raman spectroscopy. Spectrochim. Acta A 2018, 193, 63-70.

(25) Li, Y.; Liu, M.; Yuan, H.; Zhao, J. Determination of ofloxacin residue in duck meat by surface enhanced Raman spectroscopy. J. Anal. Sci. 2018, 34, 367-371. 